\title{
The ethnoecological knowledge of fishermen from three coastal lagoons in the northern of the State of Rio de Janeiro, Brazil
}

\author{
Alexandre Ferreira Lopes ${ }^{1,3}$ \& Reinaldo Luiz Bozelli ${ }^{2}$ \\ ${ }^{I}$ Departamento de Ciências do Meio Ambiente, Universidade Federal Rural do Rio de Janeiro, \\ Rio de Janeiro, RJ, Brazil. \\ ${ }^{2}$ Departamento de Ecologia, Universidade Federal do Rio de Janeiro, Rio de Janeiro, RJ, Brazil. \\ ${ }^{3}$ Corresponding author: e-mail: alexandrelopes@ufrrj.br
}

LOPES, A.F., BOZELLI, R.L. The ethnoecological knowledge of fishermen from three coastal lagoons in the northern of the State of Rio de Janeiro, Brazil. Biota Neotropica. 14(4): e20140038. http://dx.doi.org/10. 1590/1676-06032014003814

\begin{abstract}
The current study investigated the ethnoecological knowledge developed by fishermen through their fishing activities and searched for ways to match such knowledge to empirical data available in the scientific literature. The research involved fishermen from three coastal lagoons in the northern region of the State of Rio de Janeiro, Brazil, who were consulted through semi-structured interviews after the establishment of a trustful relationship over a period of three years with the interviewer. Their knowledge, in addition to its cultural and historical importance to these populations' survival, in many ways matches scientific studies based on an ethnoecological approach. Their knowledge considers reproductive aspects, feeding habits, and migratory fishing as well as the consequences and the importance of sandbar openings to estuarine-dependent species and the understanding of the consequences of sandbar openings to lagoon trophic state and other organisms' control (such as macrophytes). This set of data can contribute to the construction of plans for managing these ecosystems, in which fishermen may have a more important role than at present.
\end{abstract}

Keywords: Fishing, co-management, ethnoecology.

LOPES, A.F., BOZELLI, R.L. O conhecimento etnoecológico dos pescadores de três lagoas costeiras do norte do Estado do Rio de Janeiro, Brasil. Biota Neotropica. 14(4): e20140038. http://dx.doi.org/10.1590/ 1676-06032014003814

Resumo: O presente estudo investigou o conhecimento etnoecológico desenvolvido pelos pescadores no exercício da atividade da pesca, além disso, investigou maneiras de agregar esse conhecimento aos dados disponíveis na literatura científica. A pesquisa envolveu pescadores de três lagoas costeiras na região norte do Estado do Rio de Janeiro, Brasil, os quais foram consultados por meio de entrevistas semiestruturadas após o estabelecimento de uma relação de confiança construida ao longo de três anos. Foi observado que o conhecimento dos pescadores, além de sua importância histórica e cultural para a sobrevivência dessas populações, em muitos aspectos, é compatível com os estudos científicos baseados em uma abordagem etnoecológica. Esse conhecimento se refere aos aspectos reprodutivos, hábitos alimentares, pesca migratória, bem como as conseqüências de aberturas de barra das lagoas para as espécies de estuarino dependentes e seus efeitos no estado trófico e no controle das macrófitas aquáticas. Este conjunto de dados pode contribuir para a construção de uma proposta de manejo para esses ecossistemas, no qual os pescadores possam ter um papel mais relevante do que se apresenta atualmente. Palavras-chave: Pesca, manejo compartilhado e etnoecologia.

\section{Introduction}

Coastal lagoons are inland water bodies widely spread along the entire continental coast, and approximately $10 \%$ of these systems are located in South America (Barnes 1980). In Brazil, coastal lagoons are viewed as a very important set of freshwater ecosystems. They are distributed along the Brazilian coast mainly in the states of Rio Grande do Sul and Rio de Janeiro (Esteves 1998). Both ecologically and economically important ecosystems due to their high productivity, coastal lagoons support communities that are unique in structure and diversity, making them ecosystems that contain important features in terms of conservation (Gordon 2000). The conservation of those systems is linked to uses established by society.

In addition to the local residents, the government and researchers recognize the role played by fishermen who historically developed a relationship of direct use of fishery resources from these systems. Therefore, we use the ethnosciences in order to understand the relationship between human populations and 
these ecosystems. Ethnoecology studies concepts and knowledge regarding nature, enabling traditional societies to set and reproduce material and spiritual conditions related to their social existence by means of the appropriate management of their natural resources and ecosystems (Toledo 1990).

The present study aimed to investigate the ecological knowledge developed by fishermen through their fishing activity and to search for ways to match such knowledge to the empirical data available in the scientific literature. It is expected that the final outcomes may provide the basis for a proposal regarding the conservation of these ecosystems, one that comprises different sectors of society and respects all forms of knowledge construction.

\section{Materials and methods}

\section{Study area}

The research involved fishermen from three lagoons in the northern region of the State of Rio de Janeiro, Brazil. The three lagoons are Saquarema, Imboassica and Carapebus, the last of which is located within the boundaries of the Restinga de Jurubatiba National Park (Figure 1). Carapebus is a coastal lagoon located in Carapebus city; it is isolated from the sea by a sandbar and is part of the sandy coastal plain phytogeographical region. It has an area of $6.5 \mathrm{~km}^{2}$, with a drainage basin of $126 \mathrm{~km}^{2}$, and a mean depth of $2.4 \mathrm{~m}$. Imboassica is an impacted urban lagoon located between Rio das Ostras and Macaé cities. It has an area of $3.26 \mathrm{~km}^{2}$ with a mean depth of $1.09 \mathrm{~m}$ and a drainage basin of $50 \mathrm{~km}^{2}$ (Panosso et al. 1998).

Saquarema lagoon is located at Saquarema city and has an area of $21.2 \mathrm{~km}^{2}$ with a mean depth of $1.15 \mathrm{~m}$ and a drainage basin of $215 \mathrm{~km}^{2}$ (Wasserman 2000). This lagoon has four different compartments (Mombaça, Jardim, Boqueirão and Lagoa de Fora) and is permanently linked to the sea by a sandbar that has been opened to minimize impacts from sewage disposal.

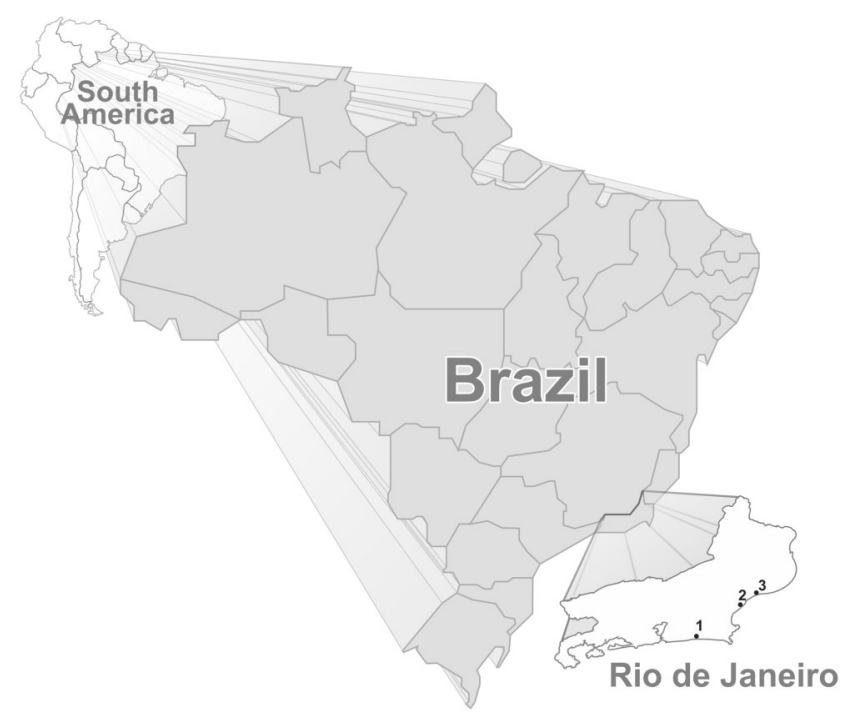

1. Saquarema: $22^{\circ} 55^{\prime} 06^{\prime \prime} \mathrm{S} 42^{\circ} 32^{\prime} 08^{\prime \prime} \mathrm{O}$

2. Imboassica: $22^{\circ} 24^{\prime} 41^{\prime \prime S} 41^{\circ} 49^{\prime} 47^{\prime \prime} \mathrm{O}$

3. Carapebus: $20^{\circ} 13^{\prime} 42^{\prime \prime} \mathrm{S} 40^{\circ} 12^{\prime} 43^{\prime \prime} \mathrm{O}$

Figure 1. Location of Saquarema lagoon (1), Imboassica lagoon (2) and Carapebus lagoon (3) (Illustration: Américo Pastor).

\section{Data sampling}

Data sampling was based on qualitative research, including field notes, interviews, chats, photographs and recordings (Quintas 2005), established over a three-year relationship with interviewees. Initially, free interviews were performed to establish mutual trust between researcher and informant. This initial approach has supported the construction of a question script and the definition of interviewees for the semi-structured interviews (Mello 1995, Elliot 2012).

Scripts for the semi-structured interviews had questions related to ecological knowledge, fishing techniques, observation, response of ecosystem to sandbar opening, and management proposals and possibilities.

To take part in the experiment, interviewees from each lagoon were chosen by snowball sampling in which some of the interviewees are previously identified and, after being interviewed, are asked to indicate new possible interviewees for the research (Biernacki \& Waldorf 1981). Initially, legitimate representatives from all lagoons were contacted. Thus, Carapebus' lagoon Residents Association former president who is the son of one of the fishermen - was interviewed. After him, two old fishermen were also interviewed. The representative from a fishermen colony at Imboassica - who also works at the Carapebus lagoon - was interviewed in public locations. He is recognized by fishermen from both colonies and other sectors of society as a local leader. At Saquarema lagoon, the interviews were initiated with the fishermen's leader. From his recommendations, two other fishermen were contacted and they indicated five more fishermen, totaling eight fishermen interviewed at this lagoon. Thus, in total, 11 fishermen were interviewed in addition to the chairman of the Association of Residents of Carapebus beach who provided important historical information. The sample was considered sufficient based on the effect of a progressive inclusion that allowed applying the criterion for completeness (Andrade et al. 2006a b). The number of interviewees was adequate for the purpose of this research, given the semi-structured interview questions, which were seeking answers of a technical nature. This research did not target issues related to personal opinions, which would have required a quantitative analysis. Moreover, as already mentioned, the fishermen have long experience in the profession and are recognized among other fishermen as leaders and experts in fisheries in coastal lagoons. The number of interviewees was similar to those used by Costa-Neto et al. (2002) and Costa-Neto (2000) in ethnoichthyological studies. It is worth noting that finding active fishermen at Imboassica lagoon is very rare, due to urbanization, as mentioned by Frota \& Caramaschi (1998). Each interview took from 30 to 70 minutes, depending on the interviewees' mood to speak with researchers. All interviews were recorded, for a total of 10 hours of recordings, which are stored at the Limnology Lab of the Federal University of Rio de Janeiro.

\section{Analysis}

The recordings were analyzed considering qualitative factors, interpreting the interviewees' speech and searching for as much contrast as possible between the ethnoecological and the scientific knowledge, according to Martins et al. (2011) and Mourão \& Nordi (2003). Therefore, based on an ethnoecological approach (Diegues 2002), we presented a data set and 
discussed the similarities and differences to available scientific knowledge.

\section{Results and discussion}

\section{Ecological aspects of ichthyofauna}

The fishermen's responses demonstrated a good range of information about the lagoons' ecology. Such knowledge was acquired through their fishing activities. Thus, it differs from scientific knowledge according to origin and validation criteria (Table 1).

Regarding fish origins, the classification system used by the fishermen is extremely similar to that suggested by the scientific community. There are several ways to classify fish from estuarine regions. Fischer et al. (2004) stated that fish are divided into estuarine residents, estuarine dependents and estuarine opportunistic, in addition to freshwater fish. The classification system proposed by the fishermen perfectly meets their needs because the most relevant issue for them is the commercial value given to the fish they catch, as observed by Ramires et al. (2012). Once marine fish hold a higher commercial value than freshwater fish, such a point of view is reasonable enough. Marine and freshwater fish are classified by the fishermen as "white fish" and "black fish", respectively. However, in spite of appearances, the fishermen's classification system shows an interesting level of complexity. Along with the issue of a fish's origin, another factor that demonstrates the logic behind the classification system proposed by the fishermen is related to the reproductive cycle of marine fish. All interviewees state that there is practically no marine fish reproduction in the lagoons, and this observation supports their arguments in favor of open sandbars in coastal lagoons. While fishermen did not list all resident species, they are aware of their existence. The species mentioned are especially those of commercial interest, which reinforces the fact that fishermen do have the knowledge that is essential for their activity. This discussion is extremely relevant because there are commercially important species in the studied lagoons, e.g., Genidens genidens (Cuvier, 1829) and Atherinella brasiliensis (Quoy \& Gaimard, 1825 ) at the Imboassica lagoon (Frota \& Caramaschi 1998), and Platanichthys platana (Regan, 1917), Genidens genidens, Atherinella brasiliensis and Jenynsia multidentata (Jenyns, 1842) at the Carapebus lagoon (Sánchez-Botero et al. 2009). Although the fish mentioned by the fishermen, such as Centropomus parallellus Poey, 1860 and Centropomus undecimalis (Bloch, 1792), are classified by the aforementioned authors as marine dependents, the complex fish classification system among the professionals is highlighted. Similar results were reported by other authors who aimed to inform about species' ethnology (Costa-Neto \& Marques 2000); taxonomy (Costa-Neto et al. 2002); habitat preferences (Moura \& Marques 2007) and seasonality (Lopes \& Begossi 2008). The studies have emphasized the criteria refinement used by the fishermen to create ethnoecological categories.

According to Sánchez-Botero et al. (2008), Mugil curema Valenciennes, 1836 and Mugil liza Valenciennes, 1836 or mullets, whose occurrence was documented in the region, are marine dependent species. Fischer et al. (2004) asserted that

Table 1. Summary information provided by fishermen

\begin{tabular}{lcl}
\hline Topic & $\%$ mentioned & Statement \\
\hline Sandbar opening & 100 & Favors species that \\
for entrance of & & $\begin{array}{l}\text { need the lagoon at } \\
\text { some life stage }\end{array}$ \\
different species & &
\end{tabular}

How was the learning of fishing Salinity at the lagoons

With father or older relatives

Increases with sandbar opening but decreases after a while

Sandbar openings 81 and improving of sanitary conditions of the lagoons

Importance of aquatic macrophytes for some fish species Variations of macrophytes stands shelters for larvae of some fish species

\section{Example}

"Because in the lagoon there are two categories of fish. Black fish and white fish. The black fish is the one that is born and reproduces in the lagoon and has low commercial value, but also important, it is a fish that do not grow too much. The white fish is the one that enters the sea, with high commercial value and reaches $10 \mathrm{Kg}, 12 \mathrm{Kg}$."

"My father... I was raised here in the lagoon"

"The tendency here is to turn into freshwater. The whole lagoon. But in 6 or 8 months it becomes brackish water. In two, three years it is freshwater."

"Because when the sewage comes, it goes to the bottom. It (sandbar opening) stirred all this mud in the bottom, those things that were quite is now emerged (...) but is leaving, it is leaving, and the sea later will renovate it."

"I guess, because I'm not a technician nor a scientist, but I guess that salt kills thousands of harmful bacteria, the exceeding vegetation, this black mud, so the salt comes in and clean it"

"Disappearing of cattails at Mombaça there are no more fish breeding sites."

$72 \quad$ Macrophytes increase with eutrophication and decrease with salinity

\footnotetext{
"We associate that the amount of sewage proliferates an amount of vegetation, disordered, in excess. Like cattails, water hyacinth..." "When it (the lagoon) fills, it brings renewed water from sea to fill enough, to reach the edge of the cattails, the cattails in excess, their roots absorb the salty water and dies, the excess, you see it does not die, the cattails are here."
} 
mullets inhabit shallow coastal waters, form shoals in order to spawn in the sea, and enter the lagoons for the estuarine phase necessary for juvenile stages (Bizerril \& Costa 2001). Such scientific information corroborates the observation by a fisherman at Imboassica lagoon that these fish leave the lagoon to spawn at sea, which usually happens in June. Costa-Neto (2000) also observed that fishermen from the State of Bahia note June as the spawning time for this species. The information from the fisherman about the mullets' reproductive cycle was obtained when he was questioned about the species' closed season and the impossibility of opening sandbars. As he said: "What is the purpose of forbidding fishing during the breeding season if they cannot breed in the lagoon and cannot leave it once the sandbars cannot be opened?"

The argument in favor of sandbar openings is based on fish reproductive cycles and is supported by the assumption that marine species ("white fish") are part of the ichthyofauna in the lagoon. The motivation for opening sandbars concerns not only fish entering lagoons but also the need for estuarine dependent species to exit the lagoons. Thus, considering that fishermen have a grasp of factors such as population fluctuation, fish biology, fishing losses and temporal factors, it was clear that their proposals regarding the lagoons' management are worth consideration.

In addition to the reproductive issue, fishermen demonstrated a good understanding about the diet of some fish species. They realized that, just as other animals, fish have a varied diet, with some feeding on plants and others on other animals - such as small crustaceans -and even on other fish. They also talked about the habit of some fish that re-suspend sediments in their search for food. This knowledge indicated that fishermen are aware of the complexity of trophic interactions in the lagoons. According to Paiva et al. (2008), Diapterus rhombeus (Cuvier, 1829) shows preference for feeding on small benthic invertebrates. Moreover, Costa-Neto \& Marques (2000) have identified- among fishermen and among the corresponding scientific literature - the awareness of foraging habits of certain species from benthic regions. Mullets, on the other hand, feed on small algae and detritus (Fischer et al. 2004) and present the strategy -mentioned by an interviewee- of re-suspending sediments in order to access items that are part of their diet. Such feeding behavior is also described by Costa-Neto \& Marques (2000) and Ramires et al. (2007).

Some species had been identified by the fishermen as predators. According to one of them, C. parallellus, Hoplias malabaricus (Bloch, 1794) and Caranx latus Agassiz, 1831, are examples of predatory fish. According to the scientific literature, these three species feed on fish and invertebrates (Silvano 2001, Sánchez-Botero et al. 2008). The first two are piscivorous, both in number of food items and consumed biomass (Loureiro \& Hahn, 1996, Toniniet al. 2007), whereas C. latus eats both fish and invertebrates, but the consumed biomass of fish is higher than the invertebrates'(Silvano 2001). Clarias gariepinus (Burchell, 1822), described by a fisherman as a "terrifying predator", presents few restrictions on feeding habits and its diet can consist of terrestrial invertebrates, aquatic insects, fish, crustaceans, mollusks, fish eggs, aquatic macrophytes and detritus (Groenewald 1964, MwebazaNdawula 1984, Spataru et al.1987, Dadebo 2000).

In addition to being aware of this species' potential, fishermen are also concerned about the impacts caused by exogenous species. They demonstrated this concern by mentioning the occurrence of Tilapia rendalli (Boulenger, 1897) and Clarias gariepinus at the Imboassica lagoon. According to Caramaschi et al. (2004), the occurrence of $T$. rendalli on 10 $\mathrm{mm}$ mesh hauls went from 34\% - between 1991 and 1993 - up to $66 \%$ - between 2000 and 2003 - at the Imboassica lagoon. According to the authors, such dominance is favored by salinity decrease during the closed periods of sandbars and by the species' colonizing ability. Fishermen have also demonstrated knowledge that the existence of exotic species can cause changes in the community. This understanding is clear to them because such changes modify species appearing in fishing nets and can bring economic losses due to a possible reduction of the availability of marine species. Despite the fact that $T$. rendalli has a good acceptance in the market, and as a result is often caught by fishermen, the species of marine origin are the most valuable for these professionals.

Fishermen's knowledge about fish feeding habits is widely discussed in ethnoecology studies. The results indicate detailed knowledge on specific criteria such as reproductive features. Fishermen recognize fish as generalists and specialists (CostaNeto \& Marques 2000), omnivorous, opportunists, carnivorous, planktivorous, iliophagous and piscivorous (Mourão \& Nordi 2003). Furthermore, Mourão \& Nordi (2003) state that the fishermen at the estuary of the Mamanguape River recognize a large variety of fish behaviors such as reproduction, sound emission, odor release, feeding, migration and protection from predators. Their behavior had also been observed by fishermen interviewed during our research. In a broader sense, Diegues (2002) states that fishermen are aware of fish behavior, location, availability and that they know about the species distribution as well as about taxonomic and habit classifications.

\section{Lagoons physical and chemical features}

Marine fish are the fishermen's primary target, but the fishermen also seem to understand other factors related to the ecosystem as a whole, such as salinity. A fisherman at Carapebus lagoon described a sequence of events that goes from salt water, right after the bar was opened, going to brackish water 6 months later and up to freshwater after a few years. Such a sequence is common in all the lagoons that have regular contact with the sea, where rain and river waters are the main sources for freshwater. Therefore, the time required for salinity reduction varies, because depending on the rainfall season, it could happen for a few months, as described by Santangelo (2009) at Imboassica lagoon, or for a year, as mentioned by the fisherman and Sánchez-Botero (2005).

A fisherman at Saquarema lagoon mentions the different salinity in distinct lagoon regions: "this first lake salinity is 35 , almost equal to sea. At Boqueirão it is 30 , and at Mombaça it is 25 according to our recent observations". Another fisherman at the same lagoon knows about the long-term changes in the salinity at Saquarema lagoon: "nowadays, it is more salty". The salinity data are corroborated by Wasserman (2000) and Azevedo (2005). The former author showed that inner lagoons' regions (Boqueirão e Mombaça) at Saquarema lagoon have lower salinity values than the region known as "Lagoa de Fora", and the latter states that after the permanent opening of the sandbar, the same region has salinity nearly equal to that of the sea. 
Still concerning salinity, the fishermen believe that sea water intrusion leads to a decrease in pathogenic bacteria proliferation; these are present in the lagoon, due to non-treated sewage outflow. The fisherman at Imboassica lagoon reported that when salinity increases, the amount of "harmful" bacteria decreases, as does the amount of vegetation (macrophytes). Mallin et al. (2000) found that the abundance of pathogenic bacteria presents a negative correlation to an increase in salinity, a fact that was confirmed by Lutterbach et al. (2001), Meirelles-Pereira (2002) and Ajayi \& Akonai (2003). Low salinity lagoons, such as Carapebus, usually have large macrophyte stands dominated by Typha domingensis Pers (Farjalla et al. 1999). On the other hand, the opposite condition was confirmed by Glenn et al. (1995) and Macek \& Rejmánková (2007). According to Palma-Silva (1998), T. domingensis is the species of the genus Typha more tolerant to brackish water and is also tolerant to seawater intrusion in Imboassica lagoon. However, considering other authors' results, such a tolerance does not prevent its decrease in periods of sandbar openings.

\section{Lagoons trophic features}

Sandbar openings, in general, are related to trophic features in lagoons. The lagoons were historically surrounded by houses (Imboassica and Saquarema), crops and industries (Carapebus) that drain their sewage into such freshwater systems. Regarding this particular subject, the fisherman at Imboassica lagoon understands important concepts about the lagoon's trophic state. This understanding could first be seen when he mentioned the sewage deposition in the sediment and also when he talked about the relationship between sandbar openings and the nutrient's excessive outputs. Fishermen at Saquarema lagoon report differences between the closed sandbar period and the current period of permanent opened sandbar. According to them, after this change in the lagoon dynamics, there was no fish mortality, which was common in earlier times. As they said: "The constant opened sandbar was good because at first there was a great deal of fish mortality; many fish died when the water heated during warm weather. That is the only advantage of this permanently opened sandbar: there is no more fish mortality". "There used to be great fish mortality. This channel was good for the lagoon. Because the sandbar is opened. The channel is opened. Since it is this way, what was the fish mortality? None."

The aforementioned mortality is related to two common phenomena in lagoons that have periodical sandbar openings: fish death caused by the sanitary conditions of the lagoon, leading to high organic matter decomposition and oxygen consumption, when the lagoon receives effluents and remains closed for a long period (Esteves 2011), and after openings that promote seawater input, leading to the death of freshwater fish (Frota \& Caramaschi 1998).

This specific case has been discussed by the scientific community; systematic openings may contribute to the export of nitrogen forms, which does not happen with phosphorus. Because phosphorus is deposited on the bottom, it is resuspended, enriching the water column, and is accumulated in the lagoons over the years (Meirelles 2003, Bozelli et al. 2009). This highlights the gaps in fishermen's knowledge. Based on this case, Johannes et al. (2000) argue that even though there are flaws in the fishermen's knowledge about the system, such gaps also exist in the scientific knowledge. Such a conclusion supports part of the present research's proposal, which does not intend to diminish the importance of a certain form of knowledge in favor of another. It is meant to reinforce the dialogue between the various existing forms of knowledge.

\section{Aquatic macrophytes}

The fishermen argued that excessive amounts of macrophytes are a problem for their activities. They reported some activities performed by the plants as well as the response to the changes caused by the sandbar openings. According to the fisherman at Imboassica lagoon, many aquatic macrophyte species are found in the lagoon. Due to sewage disposal, there is an increase in the density of some of them, which can be an obstacle for sailing.

The species mentioned by him (Nymphaea ampla (Salisb.) DC., Typha domingensis Pers and Eichhornia crassipes (Mart.) Solms are aquatic macrophytes found at Imboassica lagoon (Lopes-Ferreira 1998, Santos \& Esteves 2004). Cyperus rotundus L. and Brachiaria sp. are terrestrial and invasive worldwide species that can colonize transitional areas of aquatic systems and that can become mixed with aquatic macrophytes, depending on the water level (Ricci et al. 2000). The macrophytes mentioned by the fishermen include freefloating and attached macrophytes as well as submerged and emergent macrophytes, including charophytes.

In addition to the information given on the species found in the lagoon, the fisherman discussed the macrophytes' expansion and the consequent reduction of the water surface, and he associated the plants spreading with the increase of sewage discharge in the lagoon. Such information is quite similar to results found by Palma-Silva (1998). The author assumes that T. domingensis Pers. development is favored by eutrophication, because - near the sewage channel - the species presents higher growth rates compared to other species that are not influenced by nutrient loading. It is corroborated by Macek \& Rejmánková (2007), who state that $T$. domingensis Pers. responds mainly to nitrogen and phosphorus additions.

Despite the fact that macrophytes in excess are considered as obstacles by fishermen, its total absence is harmful for the reproductive cycles of some species as mentioned by fishermen at Saquarema lagoon. These fishermen state that "with the disappearance of cattails ( $T$. domingensis Pers.) at Mombaça, there is no more fish breeding". The use of macrophytes by different fish species in coastal lagoons is highlighted by Sánchez-Botero et al. (2008). According to them, some species are highly dependent on such environments, for both feeding in juvenile or adult stages and for using macrophytes for parental fish eggs and larval care. Similar results were found by SánchezBotero \& Araujo-Lima (2001) in floodplain lakes in the central Amazon. The authors claim that macrophyte roots create an important nursery for many species in these ecosystems, including the commercially important ones.

\section{The relevance of ethnoecological knowledge}

The type of information presented by the current study, according to its historical value, displays what we call innate relevance or, as stated by Berkes et al. (1995): "by itself and the socio-cultural value." Moreover, one should take into consideration that such knowledge "through generations ensure the sustenance of human populations by using natural resources" and that an essential factor to the present discussion is the fact that many areas are currently protected, were preserved and 
kept a high biodiversity while being inhabited and managed by traditional populations (Diegues \& Viana 2004).

When analyzed by means of an ethnoscientific point of view, the information given by the fishermen indicates a high correlation to scientific knowledge, just as it was observed in several regions of Brazil by Costa-Neto (2000), Costa-Neto \& Marques (2000), Silvano et al. (2006), Costa-Neto et al. (2002), Mourão \& Nordi (2003), Thé (2003), Silvano \& Begossi (2005), Rosa et al. (2005), Mourão \& Nordi (2006), Grando (2006), Moura \& Marques (2007), Ramires et al. (2007) and others. Thus, according to the aforementioned authors, such knowledge gives to the fishermen the status of essential partners when studying and managing ecosystems of which they are a part, exactly as stated by Berkes et al. (1998). Therefore, these people's knowledge should be taken into account by decision makers when elaborate projects of local conservation are proposed for both the maintenance of wildlife and access to this natural resource (Pereira \& Schiavetti 2010).

In general, fishermen can provide information about temporal factors (annual, seasonal, daily, lunar, tide-related), pointing to different behaviors, habitats and species abundance and stating how these influence fishing strategies. In cases in which long-term data are unavailable, older fishermen may also be the only source of information regarding historical changes in fish stocks and on environmental conditions. Fishermen's ecological knowledge can thus help improve management of fish stocks and rebuilding of marine ecosystems (Johannes et al. 2000). Nevertheless, there are cases in which observations reported by fishermen -essential to decisions regarding fishing strategies -are not supported by the ichthyological literature. They are viewed as folklore or popular belief, even with the existing gaps in scientific knowledge. Accordingly, the relevance of partnerships between scientific and local knowledge becomes evident for research development (Mourão \& Nordi 2003).

Based on the scenario presented by the current study, we refer to Gadgil \& Berkes (1991), who have proposed rethinking and rebuilding the sciences involved in ecosystems management, making these better suited to fulfill the needs of ecological sustainability and of the people who use such resources. To do so, it is imperative to maintain both biological and cultural diversity, because together, they offer a variety of practices and traditional management resource systems. In sum, collective-choice rules affect who is involved in deciding about future rules and how preferences will be aggregated (Ostrom et al. 1999).

\section{Acknowledgements}

Thanks to PPGE/UFRJ, Capes, to ICMBio, Petrobras, CNPq, Projeto Pólen, to the members of the UFRJ Limnology Lab, to Adriana de Melo Rocha and Américo Pastor, to everyone who contributed to the present research and, especially, to the fishermen who made the work possible.

\section{References}

ANDRADE, C.T.S., MARQUES, J.G.W. \& ZAPPI, D. 2006. Utilização de cactáceas por sertanejos baianos. Tipos conexivos para definir categorias utilitárias. Sitientibus Série Ciências Biológicas 6 (Etnobiologia). 3(12):3-12.

ANDRADE, C.T.S., MARQUES, J.G.W. \& ZAPPI, D. 2006. Utilização medicinal de cactáceas por sertanejos baianos. Rev. Bras. Pl. Med., Botucatu. 36(8):36-42.
AJAYI, A.O. \& AKONAI, K.A. 2003. Antibiotic sensitivity profile of microorganisms encountered in the Lagos lagoon, Nigeria. Afr. J. Biomed. Res. 6(2):79-84.

AZEVEDO, F.B.B. 2005. Modelagem da capacidade de suporte da laguna de Saquarema - RJ após a abertura de uma conexão permanente com o mar. Dissertação de mestrado, Universidade Federal Fluminense, Niterói.

BARNES,R.S.K. 1980. Coastal lagoons. Cambridge University Press.

BEGOSSI, A. 2006. Temporal stability in fishing spots: conservation and co-management in Brazilian artisanal coastal fisheries. Ecol soc. 11(1):5. http://www.ecologyandsociety.org/vol11/iss1/art5/.

BERKES, F., KISLALIOGLU, M., FOLKE, C. \& GADGIL, M. 1998. Exploring the Basic Ecological Unit: Ecosystem-like Concepts in Traditional Societies. Ecosystems. 1(5):409-415, http://dx.doi.org/10.1007/s100219900034

BERKES, F., FOLKE, C. \& GADGIL, M. 1995. Traditional ecological knowledge, biodiversity, resilience and sustainability. In Biodiversity conservation: problems and policies. (C.S. Perrings, K.G. Müler, C. FOLKE, C.S. HOLLING, \& B.O. JANSSON, eds.). Dordrecht, Kluwer Academic.

BIERNACKI, P. \& WALDORF, D. 1981. Snowball sampling problems and techniques of chain referral sampling. Sociol. Methods Res. 10(2):141-163.

BIZERRIL, C.R.S.F. \& COSTA, P.A. 2001. Peixes Marinhos do Estado do Rio de Janeiro. Rio de Janeiro: Fundação de Estudos do Mar (FEMAR) Secretaria de Estado de Meio Ambiente e Desenvolvimento Sustentável do Estado do Rio de Janeiro.

BOZELLI, R.L., CALIMAN, A., GUARIENTO, R.D., SANTANGELO, J.M., LEAL, J.J.F., ROCHA, A.M., QUESADO, L.B., MARINHO, P.L., FARJALLA, V.F \& ESTEVES, F.A. 2009. Interactive Effects of Environmental Variability and Human Impacts on the Long-Term Dynamics of Neotropical Aquatic Ecosystems. Limnologica. 39:306-313, http:// dx.doi.org/10.1016/j.limno.2009.06.004

CARAMASCHI, E.P., SÁNCHEZ-BOTERO, J.I., BRANDÃO, C.A.S., SOARES, C.L., NOVAES, J.L.C., ARAÚJO, B.R. 2004. Peixes das lagoas costeiras de Macaé: Estudos de caso. In Ecologia, História Natural e Conservação da restinga do Parque Nacional de Jurubatiba. (C.F.D. Rocha, F.A. Esteves \& F.R. Scarano, eds). Rio de Janeiro.

COSTA-NETO, E.M. 2000. Sustainable development and traditional knowledge: a case study in a brazilian artisanal fishermen's community. Sustain Dev. 8:89-95, http://dx.doi.org/10.1002/ (SICI) 1099-1719(200005)8:2<89::AID-SD130>3.0.CO;2-S

COSTA-NETO, E.M., DIAS, C.V. \& MELO, M.N. 2002. O conhecimento ictiológico tradicional dos pescadores da cidade de Barra, região do médio São Francisco, Estado da Bahia, Brasil. Acta sci. 34(11):561-573.

COSTA-NETO, E.M. \& MARQUES, J.G.W. 2000. Etnoictiologia dos pescadores artesanais de Siribinha, município de Conde (Bahia): aspectos relacionados com a etologia dos peixes. Acta Sci. 22(2):553-560.

DADEBO, E. 2000. Reproductive biology and feeding habits of the catfish Clarias gariepinus (Burchell) (Pisces: Clariidae) in lake Awassa, Ethiopia. Ethiop J Health Sci. 23(2):231-246.

DIEGUES, A.C. 2002. Traditional Fisheries Knowledge and Social Appropriation of Marine Resources in Brazil. Mare Conference: People And The Sea, Amsterdam.

DIEGUES, A.C., \& VIANA, V.M. 2004. Comunidade tradicionais e manejo dos recursos naturais na mata atlântica. $2^{\text {a }}$ Ed. Hucitec: NUPAUB. São Paulo.

ELLIOT, L.G. 2012. Instrumentos de avaliação e pesquisa: caminhos para construção e validação. Wak Editora. Rio de Janeiro.

ESTEVES, F.A. 1998. Lagoa Imboassica: impactos antrópicos, propostas mitigadoras e sua importância para a pesquisa ecológica. In Ecologia de lagoas costeiras do Parque Nacional da Restinga de 
Jurubatiba e do Município de Macaé (RJ). (F.A. Esteves, ed) Macaé..

ESTEVES, F.A. 2011. Fundamentos de Limnologia. 3. ed. Rio de Janeiro: Interciência, 2011. v. 1.

FARJALLA, V.F., MARINHO, C.C., ESTEVES, F.A. 1999. Aspects of the uptake of dissolved oxygen in the initial stages of decomposition of aquatic macrophytes and detritus from terrestrial vegetation in a tropical coastal lagoon. Acta Limnol. Bras. 11:185193.

FISHBASE. http://www.fishbase.org/home.htm (last access at 09/09/ 2014)

FISCHER, LG., PEREIRA, L.E.D. \&VIEIRA, J.P. 2004. Peixes estuarinos e costeiros. Ecoscientia. Rio Grande.

FROTA, L.O.R. \& CARAMASCHI, E.P. 1998. Aberturas artificiais de barra da Lagoa Imboassica e seus efeitos sobre a fauna de peixes. In Ecologia de lagoas costeiras do Parque Nacional da Restinga de Jurubatiba e do Município de Macaé (RJ). (F.A. Esteves, ed). Macaé.

GADGIL, M. \& BERKES, F. 1991. Traditional resource management systems. Resour Manage Opt. 8(3-4):127-141.

GLENN, E., THOMPSON, T.L., FRYE, R., RILEY, J. \& BAUMGARTNER, D. 1995. Effects of salinity on growth and evapotranspiration of Typha domingensis Pers. Aquatic Botany. 52(1-2):75-91, http://dx.doi.org/10.1016/0304-3770(95)00492-I

GORDON, C. 2000. Hypersaline lagoons as conservation habitats: macro-invertebrates at Muni Lagoon, Ghana. Biodivers Conserv. 9(4):465-478, http://dx.doi.org/10.1023/A:1008906503227

GRANDO, R.O. 2006. Conhecimento Etnoecológico de Pescadores da Praia do Forte, Litoral Norte - BA: Um Saber Ameaçado. Enciclopédia Biosfera, N.02.

GROENEWALD, A.A.V.J. 1964. Observations on the food habits of Clarias gariepinus Burchell, the South African freshwater barbel (Pisces: Clariidae) in Transvaal. Hydrobiologia. 23(1-2):287-291, http://dx.doi.org/10.1007/BF00043737

JOHANNES, R.E., FREEMAN, M.M.R. \& HAMILTON, R.J. 2000. Ignore fishers' knowledge and miss the boat. Fish Fish. 1(3):257271, http://dx.doi.org/10.1046/j.1467-2979.2000.00019.x

LOPES, P.F, M., \& BEGOSSI, A. 2008. Temporal changes in caiçara artisanal fishing and alternatives for management: a case study on the southeastern Brazilian coast. 8(2):53-62 http://www.biotaneotropica.org.br/v8n2/en/abstract?article+bn00708022008 (last access at $05 / 03 / 2014$ ).

LOPES-FERREIRA, C. 1998. Redução das concentrações de nitrogênio e fósforo dos efluentes lançados na lagoa Imboassica, através de uma região colonizada por macrófitas aquáticas. In Ecologia de lagoas costeiras do Parque Nacional da Restinga de Jurubatiba e do Município de Macaé (RJ). (F.A Esteves, ed). Macaé.

LOUREIRO, V.E. \& HAHN, N.S. 1996. Dieta e atividade alimentar, Hoplias malabaricus (Bloch, 1794) (Osteichthyes, Erythirinidae), nos primeiros anos de formação do reservatório de Segredo, PR. Acta Limnol. Bras. 8:195-205.

LUTTERBACH, M.T.S., VAZQUEZ, J.C., PINET, J.A., ANDREATA, J.V. \& SILVA, A.C. 2001. Monitoring and spatial distribution of heterotrophic bacteria and fecal coliforms in the Rodrigo de Freitas Lagoon, Rio de Janeiro, Brazil. Braz. Arch. Biol. Technol. 44(1):7-13, http://dx.doi.org/10.1590/S151689132001000100002

MACEK, P. \& REJMÁNKOVA, E. 2007. Response of emergent macrophytes to experimental nutrient and salinity additions. Funct. Ecol. 21:478-488, http://dx.doi.org/10.1111/j.1365-2435.2007. 01266.x

MALLIN, M.A., WILLIAMS, K.E., ESHAM, C.R., \& LOWE, R.R. 2000. Effect of human development on bacteriological water quality in coastal watersheds. Ecol. appl. 10(4):1047-1056, http:// dx.doi.org/10.1890/1051-0761(2000)010[1047:EOHDOB]2.0.CO;2

MARTINS, V.S., SCHIAVETTI, A. \& SOUTO, F.J.B. 2011. Ethnoecological knowledge of the artisan fishermen of octopi
(Octopus spp.) in the community of Coroa Vermelha (Santa Cruz Cabrália, Bahia). An. Acad. Bras. Cienc. 83(2):513-522, http:// dx.doi.org/10.1590/S0001-37652011000200011

MEIRELLES, F.S.P. 2003. Variação da profundidade da coluna d'água e sua influência sobre a ecologia da lagoa Imboassica (Macaé, RJ) e do lago Batata (Oriximiná, PA). Dissertação de mestrado, Universidade Federal do Rio de Janeiro. Rio de Janeiro.

MEIRELLES-PEREIRA, F. 2002. Ecological aspects of the antimicrobial resistance in bacteria of importance to human infections. Braz. J. Microbiol. 33(4):287-293.

MELLO, L.G. 1995. Antropologia Cultural: iniciação, teoria e temas. Vozes. Petrópolis.

MOURA, F.B.P. \& MARQUES, J.G.W. 2007. Conhecimento de pescadores tradicionais sobre a dinâmica espaço-temporal de recursos naturais na Chapada Diamantina, Bahia. 7(3):119-126 http://www. biotaneotropica.org.br/v7n3/pt/abstract?article+bn0180703200. (last access at 05/03/2014).

MOURÃO, J.S. \& NORDI, N. 2003. Etnoictiologia de pescadores artesanais do estuário do rio Mamanguape, Paraíba, Brasil. B. Inst. Pesca, São Paulo. 29(1):9-17.

MOURÃO, J.S. \& NORDI, N. 2006. Pescadores, peixes, espaço e tempo: uma abordagem etnoecológica. Interciencia (Caracas). 31:358-363.

MWEBAZA-NDAWULA, L. 1984. Food and feeding habits of Clarias mossambicus from four areas in the Lake Victoria basin, East Africa. Environ. Biol. Fisches. 10:69-76, http://dx.doi.org/10.1007/ BF00001663

OSTROM, E., BURGUER, J., FIELD, C.B., NORGAARD, R.B. \& POLICANSKY, D. 1999. Revisiting the commons: local lessons, global challenges. Science. 284:278-282, http://dx.doi.org/10.1126/ science.284.5412.278

PAIVA, A.C.G., CHAVES, P.T.C. \& ARAÚJO, M.E. 2008. Estrutura e organização trófica da ictiofauna de águas rasas em um estuário tropical. Rev. Bras. Zool. 25(4):647-661, http://dx.doi.org/10.1590/ S0101-81752008000400010

PALMA-SILVA, C. 1998. Crescimento e Produção de Typha domingensis Pers na lagoa Imboassica. In Ecologia de lagoas costeiras do Parque Nacional da Restinga de Jurubatiba e do Município de Macaé (RJ). (F.A. Esteves, ed). Macaé.

PANOSSO, R.F., ATTAYDE, J.L. \& MUEHE, D. 1998. Morfometria das lagoas Cabiúnas, Comprida e Carapebus: implicações para seu funcionamento e manejo. In Ecologia de lagoas costeiras do Parque Nacional da Restinga de Jurubatiba e do Município de Macaé (F.A Esteves, ed). Macaé.

PEREIRA, J.P.R \& SCHIAVETTI, A. 2010. Conhecimentos e usos da fauna cinegética pelos caçadores indígenas "Tupinambá de Olivença” (Bahia). 10(1):175-183 http://www.biotaneotropica.org. br/v10n1/ pt/abstract?article+bn03210012010. (last access at 05/03/ 2014).

QUINTAS, J.S. 2005. Introdução à gestão ambiental pública. Ibama. Brasília.

RAMIRES, M., MOLINA, S.M.G., HANAZAKI, N. 2007. Etnoecologia caiçara: o conhecimento dos pescadores artesanais sobre aspectos ecológicos da pesca Biotemas. 20(1):101-113.

RAMIRES, M., CLAUZET, M. \& BEGOSSI, A. 2012. Folk Taxonomy of Artisanal Fishermen of Ilhabela (São Paulo/Brazil). 12(4): 000-000. http://www.biotaneotropica.org.br/v12n4/pt/fullpaper? bn00412042012+en. (last access at 09/04/2014).

RICCI, M.S.F., ALMEIDA, D.J., FERNANDES, M.C.A., RIBEIRO, R.L.D. \& CANTANHEIDE, M.C.S. 2000. Efeitos da solarização do solo na densidade populacional da tiririca e na produtividade e hortaliças sob manejo orgânico. Pesq. Agropec. Bras. Brasília. 35(11):2175-2179, http://dx.doi.org/10.1590/S0100-204X2000001100008

ROSA, I.M.L., ALVES, R.R.N., BONIFÁCIO, K.M., MOURÃO, J.S., OSÓRIO, F.M., OLIVEIRA, T.P.R. \& NOTTINGHAM, M.C. 2005. Fishers' knowledge and seahorse conservation in Brazil. J Ethnobiol Ethnomed. 1:1-12, http://dx.doi.org/10.1186/17464269-1-1 
SÁNCHEZ-BOTERO, J.I. 2005. Efeitos de distúrbios naturais e antrópicos sobre a fauna ictíica em lagoas costeiras na região de Macaé / RJ. Tese de doutorado, Universidade Federal do Rio de Janeiro. Rio de Janeiro.

SÁNCHEZ-BOTERO, J.I., GARCEZ, D.S., CARAMASCHI, E.P. \& SAAD, A. 2009. Indicators of Influence of salinity in the resistance and resilience of fish assemblage in a tropical coastal lagoon (Southeastern Brazil). Bol Investig Mar Costeras. 38:52-68.

SÁNCHEZ-BOTERO, J.I., CARAMASCHI, E.P., \& GARCEZ, D.S. 2008. Spatiotemporal variation in fish assemblage in a coastal lagoon without direct contact with the sea (southeastern Brazil). J Coastal Res. 24(4C):225-238, http://dx.doi.org/10.2112/06-0752.1

SÁNCHEZ-BOTERO, J.I. \& ARAUJO-LIMA, C.A.R.M. 2001. As macrófitas aquáticas como berçário para a ictiofauna da várzea do Rio Amazonas. Acta Amazon. V. 31(3):437-447.

SANTANGELO, J.M. 2009. Estrutura do Banco de Ovos de Resistência do Zooplâncton em Sistemas Aquáticos Continentais e Influência da Salinidade e da Predação na Diapausa. Tese de doutorado, Universidade Federal do Rio de Janeiro. Rio de Janeiro.

SANTOS, A.M. \& ESTEVES, F.A. 2004. Influence of Water Level Fluctuation on the Mortality and Aboveground Biomass of the Aquatic Macrophyte Eleocharis interstincta (VAHL) Roemer et Schults. Braz Arch Biol Techn. 47(2):281-290, http://dx.doi.org/ 10.1590/S1516-89132004000200016

SILVANO, R.A.M. 2001. Feeding habits and interspecific feeding associations of Caranx latus (Carangidae) in a subtropical reef.
Environ Biol Fish. 60:465-470, http://dx.doi.org/10.1023/ A:1011064923544

SILVANO, R.A.M., MACCORD, P.F.L., LIMA, R.V. \& BEGOSSI, A. 2006. When does this fish spawn? Fishermen's local knowledge of migration and reproduction of Brazilian coastal fishes. Environ Biol Fish. 76:371-386.

SILVANO, R.A.M. \& BEGOSSI, A. 2005. Local knowledge on a cosmopolitan fish Ethnoecology of Pomatomus saltatrix (Pomatomidae) in Brazil and Australia. Fish Res. 71:43-59, http:// dx.doi.org/10.1016/j.fishres.2004.07.007

SPATARU, P., VIVEEN, W.J.A.R. \& GOPHEN, M. 1987. Food composition of Clarias gariepinus (C. lazera) (Cypriniformes, Clariidae) in Lake Kinneret (Israel). Hydrobiologia. 144:77-82, http://dx.doi.org/10.1007/BF00008053

THÉ, A.P.G. 2003. Conhecimento Ecológico, Regras de uso e Manejo local dos Recursos Naturais na Pesca do Alto-Médio São Francisco, MG. Tese de doutorado, Universidade Federal de São Carlos. São Carlos.

TOLEDO, V.M. 1990. La Perspectiva Etnoecológica: Cinco Reflexiones Acerca de las "Ciencias Campesinas" Sobre la Naturaleza con especial Referencia a México. Ciências. 4:22-29.

TONINI, W.C.T., BRAGA, L.G.T., VILA NOVA, D.L.D. 2007. Nova dieta de juvenis do robalo Centropomus parallellus Poey, 1860 no sul da Bahia, Brasil. B. Inst. Pesca. São Paulo. 33(1):85-91.

WASSERMAN, J.C. 2000. Estudo do Impacto Ambiental da Barra Franca na Lagoa de Saquarema/Relatório de Impacto Ambiental da Barra Franca na Lagoa de Saquarema - RJ. 